\title{
COVID-19: İmmün Patogenez
}

\section{COVID-19: Immunopathogenesis}

\author{
Deniz MAVil(iiD), Ahmet Çag̃kan iNKAYA²(iD)
}

\author{
${ }^{1}$ Hacettepe Üniversitesi Tıp Fakültesi, Ankara, Türkiye \\ ${ }^{2}$ Hacettepe Üniversitesi Tıp Fakültesi, İnfeksiyon Hastalıkları ve Klinik Mikrobiyoloji Anabilim Dalı, Ankara, Türkiye
}

Makale atıf: Mavi D, Inkaya AÇ. COVID-19: Immün patogenez. FLORA 2020;25(2):121-31.

\section{ÖZ}

Koronavirüs-19 hastalığı (COVID-19), ilk kez 2019 yılı sonunda Çin'in Wuhan şehrinde tanımlanmıştır. Hızla tüm dünyaya yayılarak, üç yüz binden fazla insanın ölümüne neden olmuştur. Henüz bilinen etkin aşı ve tedavisi yoktur. Hastalık patogenezi anlaşılmadan aşı ve özgün tedavi geliştirilmesi mümkün değildir. Ağır solunum yetmezlik sendromu koronavirüsü (SARS-CoV) ve Ortadoğu solunum sendromu koronavirüsü (MERS-CoV) salgınlarından elde edilen bilgiler, COVID-19 patogenezinin aydınlatılmasına katkı sağlayabilir. Yapılan tüm çalışmalara rağmen SARS-CoV-2 patogenezinde pek çok nokta hala tam olarak anlaşılamamıştır. Aşırı immün yanıtın ortaya çıkması, solunum yetmezliği ve hatta ölüme kadar gidebilen komplikasyonlara yol açar. COVID-19 sırasında kompleman sistemi, sitokin salınımı ve inflamasyon, endotel hasarı, koagülasyon kaskadı, hücresel ve hümoral immünite hepsi birlikte immün patogenezde oldukça önemli bir rol oynamaktadır. Bu derlemede; COVID-19'un ortaya çıkışı, SARS-CoV-2'ye karşı oluşan immün yanıt ve konak özelliklerinin hastalığın ciddiyeti ile olan ilişkisi, antikor yanıtları ve immün patogenez, hiperkoagülasyonun olası nedenleri tartışılacak olup etkili bir aşı ve spesifik tedavi geliştirilmesi yolunda perspektif kazandırma amaçlanmıştır.

Anahtar Kelimeler: SARS-CoV; SARS-CoV-2; COVID-19; immün patogenez; Sitokin fırtınası

\section{ABSTRACT}

\section{COVID-19: Immunopathogenesis}

\section{Deniz MAVi', Ahmet Çag̃kan iNKAYA²}

\footnotetext{
${ }^{1}$ Faculty of Medicine, University of Hacettepe, Ankara, Turkey

2 Department of Infectious Diseases and Clinical Microbiology, Faculty of Medicine, University of Hacettepe, Ankara, Turkey
}

Coronavirus-19 disease (COVID-19) first described in Wuhan, China at the end of 2019. It spread rapidly all over the world and claimed the lives of over 300,000 people. There is no known effective vaccine and treatment yet. It is impossible to develop vaccines and specific treatment without understanding the pathogenesis of the disease. Experience from severe acute respiratory syndrome coronavirus (SARS-CoV) and Middle East respiratory syndrome coronavirus (MERS-CoV) outbreaks may help to elucidate the pathogenesis of COVID-19. Nevertheless, many issues remained obscure regarding the pathogenesis of SARS-CoV-2. Exaggerated immune response leads to respiratory failure and even complications which may culminate in death. Cytokines storm, the complement system, endothelial damage, coagulation cascade, cellular and humoral immunity all play an important role in immune pathogenesis and inflammation. In

Geliș Tarihi/Received: 16/05/2020 - Kabul Ediliș Tarihi/Accepted: 17/05/2020

${ }^{\circ}$ Telif Haklı 2020 Flora. Makale metnine www.floradergisi.org web adresinden ulașılabilir. 
this review, the relationship between the immune response/host characteristics of SARS-CoV-2 and the severity of the disease, antibody responses, and immune pathogenesis, possible causes of hypercoagulation will be discussed and it's aimed to provide perspective on the development of effective vaccines and specific treatment.

\section{GíRiș}

Koronavirüs-19 hastalığı (COVID-19) ilk olarak Cin'in Hubei eyaletinin Wuhan sehrinde tanımlanmıștır ${ }^{[1]}$. Benzer solunum yolu infeksiyonu sikayetleriyle hastaneye bașvuran kiși sayısındaki artısın fark edilmesi ve etken virüsün tanımlanmas1 bir aydan kısa sürede gerceklesmiștir. Hastalık etkeni bir RNA virüsüdür ve SARS-CoV-2 olarak isimlendirilmiștir ${ }^{[2]}$. Asemptomatik kisilerin ve hastaların solunumsal cıkartılarıyla, damlacık yoluyla veya direkt olarak temas, en önemli bulas yoludur. İnsandan insana hizla bulasabilmesi hastal1ğın kontrolünün önündeki en önemli zorluktur ${ }^{[2,3]}$. Dünya Sağllk Örgütü (DSÖ) verilerine göre onaylanmıs olgu sayısı 4,3 milyonu, ölüm sayısı 300 bini geçmiștir ${ }^{[4]}$. Yayılımını önlemek adına dünya genelinde cok ciddi önlemler alınmasına rağmen, sağlık sistemlerini ve insan yașamını tehdit etmeye devam etmektedir.

COVID-19 sadece bir solunum yolu hastalığ1 değil coklu organ tutulumuyla giden bir tablodur ${ }^{[5]}$. Su anda hastalığın immün patogenezi tam anlamıyla cözülebilmiș değildir. Var olan bilimsel veriler antikor bağıml güçlendirme (ADE-antibody-dependent enhancement), sistemik inflamatuvar yanit, $\mathrm{T}$ hücre așırı aktivasyonu ve anjiyotensin dönüștürürcü enzim 2 (ACE2) reseptör down-regülasyonu, pnömositlere karș1 gelisen antikor capraz reaksiyonu gibi patogenezde etkili olabilecek birçok olası mekanizmay1 isaret etmektedir ${ }^{[5,6]}$.

\section{SARS-CoV-2'NIN VIROLOJiK ÖZELLIKLERI}

COVID-19 etkeni olan SARS-CoV-2; Coronaviridae ailesinden, segmentsiz, tek zincirli, pozitif polariteli bir RNA virüsüdür ${ }^{[7]}$. Koronavirüsler kus, deve, yarasa, misk kedisi, fare, kedi ve köpek gibi insan dıșı konakları da infekte edebilir ${ }^{[8]}$. İnsanlarda koronavirüs infeksiyonu genelde hafif seyirli bir tablo olușturur. Halbuki 2002 yilinda Cin'in Guangdong eyaletinde ortaya cıkan ağır solunum yetmezlik sendromu (SARS) ve 2012 yllinda ilk olarak Suudi Arabistan'da teshis edilen Orta Doğu solunum sendromu (MERS) ciddi solunum yolu hastalığına neden olur ${ }^{[8-10]}$.

Coronaviridae içinde alfacoronavirus, betacoronavirus, gamacoronavirus ve deltacoronavirus olarak adlandırılan dört alt cins vardır. Cinsler arasında genom düzeyinde benzerlik \%54 kadardır. Yapısal genleri kodlayan gen bölgeleri cinsler arasında belirgin farkll11k göstermektedir. Bu da koronavirüslerin farklı konaklara adapte olabilmesini sağlar. Virüsün, ortalama çapı 60-140 nm, yuvarlak ve cevresi çkıntılarla sarılıdır ${ }^{[11]}$. Koronavirüs genomu $40 \mathrm{~kb}$ olup, bir RNA virüsü için oldukça büyüktür ${ }^{[12]}$. SARS-CoV-2 genomu tipik koronavirüslere benzer ve 10 farklı ORF (open reading frame) içerir. ORF1a/b; poliprotein/la ve poliprotein/1ab olmak üzere iki büyük poliproteini kodlar. Poliprotein 1a ve 1ab, genomik RNA esas alınarak sentezlenen virüsün yapisal olmayan proteinleridir. Bu iki poliprotein, viral replikasyon-transkripsiyon kompleksini olușturan 16 yapısal olmayan proteine (nsp1-nsp16) dönüșür. Nsp1-16, endoplazmik retikulum (ER)'dan köken alan membranları, sonrasında virüsün çift katmanlı zarflarını olușturacak olan veziküllere dönüștürür. Viral replikasyon ve transkripsiyon bu veziküllerin içinde nsp'lerin olușturduğu replikasyon-transkripsiyon kompleksi sayesinde gerçekleșir. Diğer ORF'ler ise spike (S), envelop (E), nükleokapsid (N) ve membran (M) proteinleri gibi dört ana yapisal protein kodlar ${ }^{[13]}$. SARS-CoV-2 genom yapis1, beta-koronavirüs cinsi virüslere benzemektedir. Genom sekans verisine göre özellikle yarasa-SL-CoVZC45 ve yarasa-SL-CoV ZXC21 isimli yabanıl hayatta tespit edilmis virüslerle benzerlik göstermekte; SARS-CoV'dan farklilașmaktadır. SARS-CoV-2'nin hücreye girișinde ACE2 reseptörüne bağlanmasının kritik önemi olduğu düșünülmektedir ${ }^{[8,12]}$.

Koronavirüs dört farkl yapısal proteini virüsün hayat döngüsünde önemli ișlevler görür. Virüs yüzeyindeki cıkıntıları olușturan $S$ protein homotrimeri hedef hücre membranına bağlanmak$\tan$ sorumludur ${ }^{[14]}$. M proteini, viriona sekil verir 
ve nükleokapside bağlanır; ayrıca viral partikülün olusturulması ve tomurcuklanarak hücreden ayrilmasında da önemlidir ${ }^{[15]}$. E proteini virüs toparlanmasında, salınmasında ve viral patogenezde rol oynar ${ }^{[16]}$. Virüsün $\mathrm{N}$ proteini pek cok ișleve sahiptir. N proteini iki farklı bölgesi üzerinden viral RNA'ya bağlanabilme kapasitesindedir. Nsp3 proteini üzerinden genomu birlestirerek virion içerinde paketler. Ayrıca ceșitli hücre içi savunma sistemlerine karș1 virüsün bütünlüğünü devam ettiriri ${ }^{[12]}$.

\section{SARS-CoV-2'NIN HÜCRE IÇíNE GIRIȘi}

SARS-CoV-2'nin aynı SARS-CoV'da olduğu gibi birçok farklı mekanizma ile hücre içine girebildiği gösterilmiștir. $\mathrm{Bu}$ mekanizmalardan ilki ve muhtemelen en önemlisi ACE2 reseptörleri aracilı̆̆ıla gerçekleștirdiği direkt membran füzyonudur. S proteini ACE2 reseptörlerine bağlanır ve plazma membranı ile birlesir. SARS-CoV'a ait $S$ proteini, ACE2 reseptörüne bağlandıktan sonra proteolizise uğrar ve bu virüs hayat döngüsü için önemli bir așamadır ${ }^{[17]}$. SARS-CoV-2 infeksiyonu için proteolizis basamağının gerekip gerekmediği bilinmemektedir. Kısa bir süre önce yayımlanan bir baska makalede SARS-CoV-2 S proteinin, MERS-CoV'un hücre içine giris için kullandığı DPP4 reseptörüne, tam da MERS-CoV bağlanma bölgesinden bağlanabileceği gözlenmiștir ${ }^{[18]}$. SARSCoV-2'nin hücre içine giriș mekanizması hakkında bilgilerimiz gelișmeye açıtır. SARS-CoV-2, hücre yüzey elemanlarına temasını takiben, viral inklüzyon cisimcikleri seklinde hücre içerisine alınır. Membran füzyonu haricinde "clathrin" bağımlı ve bağımsız olarak endositoz mekanizmaları da gösterilmiștir. Hücre içerisine alınan pozitif polariteli tek zincirli RNA genomu sitoplazma içerisine salınır; viral ürünlerin transkripsiyonu ve translasyonu gerçeklestirilir ${ }^{[3]}$. ACE2 reseptörleri akciğer, bağırsak, kalp, böbrek gibi birçok dokuda bulunmaktadır. Endotel hücrelerinde de ACE2 reseptörü mevcuttur ve virüsle karșlaștıktan sonra endotel hücrelerinin içerisinde viral inklüzyonlar gözlenebilir. ACE2'nin virüs giriși sırasında hücre içerisine alınması ve parcalanması renin-anjiyotensin sistemini (RAS) de etkileyerek, anjiyotensin-2 artıșına sebep olmaktadır. Endotel hücresinin infeksiyonu neticesinde olușan endotelyitis, apopitoz ve RAS dengesindeki bozulma; iskemi, ödem, hiperkoagülabilite ve benzeri birçok duruma yol açar ${ }^{[19,20]}$.
Ayrıca COVID-19; hastalarda gözlenebilen inme ve hipertansif kriz gibi durumlarla da iliskili olabilir $^{[11]}$

SARS-CoV-2'nin hücre içerisine bir diğer giris yolu ise ADE (antibody-dependent enhancement/ antikor-bağımlı güçlendirme) olabilir. ADE, dengue virüsü, ebola virüsü, insan immünyetmezlik virüsü (HIV) ve SARS-CoV gibi birçok virüs infeksiyonunda tanımlanmıștır. Virüs, anti-S antikorlarının varlığında, yüzeyinde $\mathrm{Fc}-\gamma-2$ (CD32) reseptörü bulunan hücrelere antikor-virüs kompleksi seklinde girer ve müteakiben sitopatik etki gösterebilir. ADE ile monosit-makrofaj hücrelerine giren SARS-CoV'un, sitokin/kemokin salınımı ve hücre apopitozu üzerine etkileri olabileceği düșünülmektedir. Virüs bu yolla hücreye girebilmesine rağmen, hücre içinde coğalabildiği ve sonrasında hücreden dıșarıya salındığı ispatlanamamıștır. ADE yoluyla girdiği makrofajlarda abortif infeksiyon yapmaktadır ${ }^{[21,22]}$. ADE'nin; sitotoksisite, eozinofilik immünopatoloji, nötralizan antikor yantları, sitokin/kemokin salınımı, infektivite ve apopitoz gibi durumlara etkisi hala üzerinde calıṣlması gereken ciddi bir araștırma konusudur ${ }^{[21]}$. Elimizde yeterli kanıtlar olmamakla birlikte ADE fenomeninin çoğu hastada gözlemlenen lenfopeni durumunun ortaya c1kmasında da etkili olabilmesi muhtemeldir.

MT-2 $\mathrm{T}$ lenfosit hücre hattı üzerinde yapilan bir çalıșmada SARS-CoV-2'nin bahsi geçen $\mathrm{T}$ lenfositlere; $\mathrm{S}$ protein aracilı membran füzyonu ile bağlandığı ve reseptör aracılı endositoz yolağı üzerinden giriș yaptığı da gözlenmiștir. İnfekte $\mathrm{T}$ lenfositlerin kümeler olușturdukları dikkat cekmiștir ${ }^{[23]}$. Her ne kadar SARS-CoV-2; T lenfositlerine girebilse de bu hücrelerde abortif infeksiyon yapt1$\breve{g} 1$ görülmüstür. T lenfositlerine giris yapan virüsün hücre apopitozunda ne derece etkili olduğu ise hala ileri araștırma gerektiren bir konudur ${ }^{[24]}$. T lenfositlerinin yüzeyinde bulunan CD147 reseptörlerinin virüsün $\mathrm{S}$ proteini aracllhğ1 ile hücreye girișinde etkili olabileceği düșuinülmüștür ${ }^{25]}$. T lenfosit kümelenmesi ve $\mathrm{T}$ hücre apopitozu lenfositopeni patogenezinde önemli olabilir.

\section{SARS-CoV-2'YE KARŞI GELIȘEN IMMÜN YANITLAR}

Koronavirüs infeksiyonuna karș1 ceșitli mekanizmalarla immün yanıt olușmaktadır. Doğal 
immün yanıtın olușmasında en önemli etken virüsün lipid, protein ve nükleik asit formundaki [pathogen-associated molecular pattern (PAMP)] yapılarının toll-benzeri reseptörler (TLR) tarafından tanınmasıdır. S proteininin TLR4, ssRNA'nın TLR7/8 ve replikasyon sirasinda ortaya cikan dsRNA'nın ise TLR3 tarafından tanınabileceği öngörülmektedir. TLR3 ve TLR4, TRIF (toll-interleukin 1 receptor domain-containing adapter-inducing interferon- $\beta$ ) ve TRAM (TRIF-related adapteur molecule) üzerinden IRF-3 (interferon regulatory factor 3)'ü indüklemekte ve IRF3 cekirdeğe giderek interferon (IFN) sentezini bașlatmaktadır. TLR7/8 ve TLR4 ise MYD88 (myeloid differentiation primary response 88) aracilığıla IRAK (interleukin-1 receptor-associated kinase)'1 indüklemektedir. IRAK; NF-кB (nuclear factor kappa B) aracılı̆̆ıla pro-inflamatuvar sitokin ve kemokin sentezini bașlatmaktadır. Özetle, hücre kendi içerisindeki yabancı veya bozulmus molekülü algılamakta ve hatanın düzeltilmesi için çevresindeki hücrelere uyarılar yapmaktadır. Bu yolaklar virüse karșı gelișen doğal immün yanıtın önemli bileșenleridir ${ }^{[26]}$. Koronavirüsler, gerek PAMP'larını gizleyebilme gerekse de hücre içi reseptörlerin kendilerini tanımasını engelleyebilme kapasitesine sahiptir. Koronavirüsler konağın kendilerini tanımasını engellemek için ceșitli mekanizmalar geliștirmiștir ${ }^{[27-29]}$. Bu mekanizmalar arasında cift katmanlı endozomal yapıların içine saklanma, infeksiyona karșı IFN yanıtının düzeyini ve zamanlamasını bozma yer almaktadir ${ }^{[13]}$.

Antijen sunumu immünolojik yanitın basslatıc1sıdir. SARS-CoV-2 infeksiyonu sirasında antijen sunumu hakkında yeterli bilgimiz olușmamıștır. Önceki SARS ve MERS deneyimlerimizi temel alacak olursak, SARS-CoV antijen sunumu temel olarak MHC Class1 üzerinden olmaktadır. SARSCoV'a yatkınlığı arttırdığı bilinen MHC tipleri, HLA-B*4601, HLA-B*0703, HLA-DR B1*1202 ve HLA-Cw*0801 olarak saptanmıs; HLA-DR0301, HLA-Cw1502 ve HLA-A*0201 alleli tassiyanlar hastalığa direnç göstermiștir ${ }^{[30-32]}$. Gene antijen sunumuyla ilgili olarak mannoz bağlayan lektin (MBL) gen bölgesindeki polimorfizmler de SARS$\mathrm{CoV}$ için yatkınlık olușturmaktadır ${ }^{[33]}$. MERSCoV'a yatkınlık sağlayan genler HLA-DRB1*11:01 ve HLA-DQB1*02:0 olarak tespit edilmistir ${ }^{[34]}$.
SARS-CoV ve diğer koronavirüsler, kendilerine karșı olușan IFN aracılı immün yantlara duyarl1 olsalar da tip I IFN aracilı öldürmeye direnc sağlayacak ceșitli mekanizmalar da ihtiva ederler. Bu sayede konağın immün gözetiminden kaçar ve ağır hasar meydana getirebilirler ${ }^{[35,36]}$. Doğa; evrimsel surrecte, viral infeksiyonlarla bașa çkabilme için IFN gibi önemli bir mekanizma olușturmuștur. IFN yanıtı SARS-CoV-2 infeksiyonunu sinırlandırmak için önemlidir ancak yukarıda anlatılan sebep ve daha bilinmeyen bazı sebeplerden ötürü IFN yanıtları gec olușmaktadır. Gec IFN yanıtı ise sitokin fırtınasıyla ilișkili olabilirr ${ }^{[13]}$

$T$ ve $B$ lenfositler virüsün neden olduğu hasarın sınırlandırılmasında önemli bir yere sahiptir. SARS-CoV infeksiyonu sırasında akciğeri infiltre eden hücrelerin \%80'i CD8 pozitif sitotoksik T hücrelerdir ${ }^{[37]}$. SARS-CoV için fareler üzerinde yapılan calıșmalarda virüs klerensinde ve konak savunmasında $\mathrm{T}$ hücrelerinin gerekli olduğu; zayıf virüs-spesifik $\mathrm{T}$ hücre yanıtının ciddi hastalık gelișimi ile ilișkili olduğu sonucuna varılmıștır. T hücre defekti olan fare modeli geliștirilmiș ve $T$ hücrelerinin MERS hastalığındaki önemi arașt1rılmıștır ${ }^{[38]}$. Viral infeksiyonların klerensi için etkin bir $\mathrm{T}$ hücre yanıtının gerektiği bilinmektedir. SARS-CoV-2 infeksiyon modelinde de $\mathrm{T}$ hücre yanıtları önemlidir. COVID-19 hastalarında lenfopeni geliștiği ve bunun da prognostik önemi olduğu bilinmektedir. COVID-19 hastalarında periferik CD4/CD8 hücre oranları değișmemektedir. CD4 belirtec ekspresyonu anlaml sekilde değișmezken, lenfosit yüzeyindeki CD8 yoğunluğunda artıș olduğu gözlenmiștir. CD8 proteininin hücrenin sitotoksik aktivitesi üzerine etkisi düșünüldüğünde CTL (sitotoksik T lenfosit)'nin uygun bir antiviral aktivite olușturabilmek adına CD8 ekspresyonunu artırdığı savlanmaktadır ${ }^{[39]}$. Insanlarda, SARS-CoV-spesifik hafiza $\mathrm{T}$ hücreleri, infeksiyondan sonra altı yıla kadar kanda saptanabilmiștir. Buna karșın spesifik hafıza B hücresi yanıtındaki eksiklik dikkat cekmektedir ${ }^{[40]}$. SARS-CoV-2 için uzun dönem sonuçların incelenmesi gerekli olsa da eldeki veriler șu an için $\mathrm{T}$ hücre aracılı immün yanıtın virüsle tekrar infekte olmaktan korunmada önemli olabileceğini göstermektedir.

Hastallk sürecinde; hastaların periferik kan toplam lenfosit sayısı, CD4 pozitif ve CD8 pozitif $\mathrm{T}$ 
hücreleri (CD4/CD8 oranı korunarak), B lenfosit ve NK hücre sayıları azalır ${ }^{[41]}$. Hafıza yardımc1 $T$ hücreler ve $T$ regülatör hücre sayısı dikkat çekecek ölçüde düșüktürr ${ }^{42]}$. Illave olarak daha ağır hastalığ1 olanlarda; hastalığ1 hafif gecirenlere kıyasla toplam lenfosit, $\mathrm{CD} 4$ ve $\mathrm{CD} 8$ pozitif $\mathrm{T}$ hücre ve $B$ lenfosit sayıları daha da düșük bulunmuștur ${ }^{[41]}$. Periferik kan lenfosit analizlerinde hastalığ1 siddetli geçiren kișilerin periferik kan analizlerinde CD4 ve $\mathrm{CD} 8$ hücrelerde HLA DR ekspresyonu artmıştır. Illave olarak $\mathrm{CD} 4+, \mathrm{CCR} 4+, \mathrm{CCR} 6+, \mathrm{Th} 17$ hücrelerde de artıs gözlenmiștir [43]. Daha da ilginc olarak otopsi sonuçları, ikincil lenfoid dokuların da hastallk sürecinde tahrip olduğunu göstermektedir. Akciğer incelemelerinde CD4 pozitif hücrelerden zengin bir infiltrat dikkat cekmektedir ${ }^{[44]}$. Dikkat cekici bir diğer bulgu ise infiltre eden hücrelerin pek çoğu aktive lenfositlerdir.

Akut hastalık döneminde kan C-reaktif protein (CRP) ve interlökin (IL)-6 düzeyleri yüksektir. Hastaların klinik olarak iyileșmesiyle, bozulan lenfosit düzeyleri yeniden normale dönmektedir. Elimizdeki kanitlar, sitotoksik immünitenin antiviral mekanizmalarda yer aldığını ve sitotoksik immün yanıtın iyileșmesinin infeksiyonun düzelmesine neden olabileceğini ișaret etmektedir. SARS ve MERS hastalığı sırasında yapılan gözlemler $\mathrm{CD} 4 \mathrm{~T}$ hücre deplesyonunun; lenfositlerin akciğerde birikmesini engellediğini, nötralizan antikor ve sitokin yanitlarını azalttığını ortaya çıarmıștır ${ }^{[45]}$. COVID-19 geçiren immün baskılanmıs hastalarda uzamıs viral saçılım olması ve antikor olușmaması da önceki gözlemlerle uyumludur.

\section{ANTIKOR YANITLARI}

S proteini üzerindeki 437-445. aminoasitleri içeren bölgeye uygun peptidlerle MERS'e karș1 olușan immün yanıt araștırılmıștır. Bu bölge $\mathrm{B}$ hücreleri için yüksek antijenisite bölgesi olup bilgisayar modellerinde pek cok MHC alleliyle uyumlu bulunmaktadir ${ }^{[46,47]}$. Bilimsel veriler, hümoral immünitenin persistan koronavirüs infeksiyonunu engellemede elzem olduğunu ortaya koymaktadır. MERS'den kurtulan kisilerde daha pek cok antikor tanımlanmıștır ${ }^{[26]}$. MERS virüsü üzerinde yapılan arastırmalarda transjenik farelerde en az 20 farklı antikorun etkili olabileceği saptanmıștır. Bu blokan antikorlar daha ziyade virüsün $S$ proteini ve virü- sün hücre içine girerken kullandığ bölgeye karș1 geliștirilen antikorlardır ${ }^{[48,49]}$.

MERS-CoV ile infekte olmus bazı insan dıșı primat modellerinde monoklonal antikor (antiMERS-CoV RBD Therapeutic Antibody-m336) uygulamasının hastalığın siddetini azalttığı; yüksek titrede hiperimmün plazma uygulamasının ise hem solunum yollarındaki viral yükü azalttığı hem de hastalık siddetinde azalmaya yol actığı görülmüsstür. Monoklonal antikorların hastalığın siddetini azalttığı gösterilmesine rağmen solunum yollarındaki viral yüke etkisinin anlamlı olmadığı sonucuna ulașilmıștır ${ }^{[50]}$.

COVID-19 seyri sırasinda, IgM ve IgG tipi antikorlar olușmaktadır. İnfeksiyonun 15. gününden sonra hastaların ekseriyetinde IgM tipi, \%94.2'sinde IgG tipi antikorlar saptanabilmektedir ${ }^{[51]}$. Antikor yanıtının gelișmesi, hastalığın iyileșmesine paralel olmaktadır.

SARS-CoV için yapilan çalıșmalarda ates bașlangıc1 orijin alınarak IgG ve IgM tipi antikor yanitları gün gün izlenmiștir. İlk hafta IgG ve IgM antikorlarını pozitifleșmeye bașladığı görülmüștür. Semptom sonrası, 8-14 gün arasinda hastaların yaklașık yarısında bu antikorlar olușmuștur. IgM antikorlarının tanıdan sonra bir ay kadar yükselme eğiliminde olduğu ve birinci ayda yaklașık \%70 hastada bu antikorların pozitif olduğu gözükmektedir. IgG antikorlarına baktığımızda ise 36 . günden itibaren hastaların tamamında bu tipteki antikorların pozitif olduğu görülmektedir. Daha sonrasında iyileșen hastaların hastaneden çkıștan sonra da takiplerine devam edilmiștir. IgM antikorları beșinci haftadan sonra ciddi ssekilde azalmaya bașlamıs ve 11. haftadan sonra tespit edilemez olmuștur. IgG antikorları ise takip edilen süre icerisinde hastaların tamamında pozitif kalmıstır ${ }^{[52]}$. SARSCoV-2'nin yeni bir virüs olmasindan ötürü uzun dönem antikor yanıtlarının nasıl olacağı bilimsel temelli bir tahminden öteye geçememektedir. Elimizdeki veriler ise kısa dönemde su sonuçları isaret etmektedir: ortanca serokonversiyon zamanı hastalık başlangıcından itibaren IgM için 12 gün, IgG için ise 14 gün seklindedir. \%40'tan daha az hastada ilk hafta içinde bu antikorlara rastlanmıștır. İlk 15 gün içinde ise antikorlara rastlanma oran1 \%94.3 (IgM) ve \%79.8 (IgG) seklindedir. 
Serokonversiyon oranı ve antikor seviyeleri ilk iki hafta içerisinde hızlıca yükselmiștir. On birinci günde kümülatif serokonversiyon oranı \%50'ye, 39. günde \%100'e ulașmıstır [51].

SARS-CoV deneyiminden hareketle SARSCoV-2 için öne sürülen bakıș açısı, gelișen antikor yanitinin hem korunmada hem de immün aracılı yıkımda rol oynayabileceğidir. Virüs spesifik, nötralizan olmayan, düsük konsantrasyondaki antikorlar, yukarıda bahsi geçen ADE aracılığıla monosit, makrofaj ve B-lenfositler gibi FcR eksprese eden hücrelere virüs girișini arttırabilir. Antikor miktarı arttıkça ADE etkisi azalır. ADE ile hücreye giriși sağlanan virüs, hücrelerde replike olamasa da endozom içindeki immün kompleks ve serbest viral RNA üzerinden TLR3, TLR7 ve/ veya TLR8'i uyarır. TLR aktivasyonu ise proinflamatuvar ve antiinflamatuvar sitokin salınımına yol açar $^{[53]}$. ADE ile makrofaj içine alınan virüsün tümör nekroz faktörü (TNF) ve IL-6 salınımını artırabildiği gösterilmiștir ${ }^{[22]}$. Ayrıca, ADE'nin IL-10 ve "transforming growth factor" (TGF)- $\beta$ gibi antiinflamatuvar sitokinleri azalttığ1; CCL2 ve CCL3 gibi proinflamatuvar kemokinleri artırdığı gösterilmiștir [54].

$\mathrm{S}$ proteini ve $\mathrm{N}$ proteini içeren viral vektör aşılarının etkileri ayrı ayrı incelendiğinde farklı antikorların olumlu ve olumsuz etkileri olabileceği gösterilmiștir. $\mathrm{N}$ proteini ile immünize olmuș sıçanlarda proinflamatuvar sitokin sekresyonunda, nötrofilik ve eozinofilik akciğer infiltrasyonunda artış ve daha fazla ciddi akciğer patolojisi gözlenmiștir. S proteininin ise farklı epitoplarının apayrı etkileri olabilmektedir. İnsan dıșı primatlarda, S proteininin RBD ve HR2 domainine karș1 gelișmiș antikorlarının daha koruyucu olabildiği gösterilmiștir. Buna karșı diğer bazı $S$ protein epitoplarına karșı gelișmis antikorların ADE'ye yol actığı gözlenmiștir. Özellikle HR2 (Heptad Repeat 2) bölgesini hedef alan nötralizan antikorlar, $S$ protein aracilı viral füzyonu engelleyebilmektedir. Nötralizan antikorlar; kompleman, fagositler ve NK hücreler dahil birçok immün komponent ile etkilesmektedir. IgM tipi antikorlar daha cok kompleman aktivasyonu ve proinflamatuvar sitokin salınımı ile ilișkiliyken, IgG tipi antikorlar ise daha cok FcR eksprese eden hücreler üzerinden immün yanıt olușturmaktadır ${ }^{[53]}$. SARS-CoV-2 nük- leokapsid proteinine karșı olușmuș IgG ve IgM tipi antikorların incelendiği bașka bir çalıșmada; bu antikorların erken, güclü yanıtının ve yüksek titrelerinin siddetli hastalı gelișimi ile anlamlı bir sekilde uyumlu olduğu görülmüștür. Zayıf IgG yanıtı daha yüksek viral klerensle uyumlu bulunmuștur. Bu veriler ıșığında güçlü antikor yanıtının hastalı siddetiyle, zayıf antikor yanitının ise viral klerensle ilișkili olduğu gibi beklenmedik bir yoruma var1labilmektedir ${ }^{[55]}$.

$S$ proteininin reseptör bağlanma bölgesine (RBD) karșı gelișmiș RBD-spesifik antikorlar, semptomların bașlamasından sonraki sekizinci günde coğu hastada tespit edilebilmiștir. Polimeraz zincir reaksiyonu (PCR) doğrulamasını müteakip altı gün içinde bütün hastalarda RBD-spesifik IgG tespit edilebilmiștir. Nötralizan antikor yanıtlar1nın RBD-spesifik IgG titreleri ile korele olduğu gözlenmiștir. Güçlü hümoral yanıt; ciddi ve orta COVID-19 infeksiyonu sirasinda daha erken ortaya cıkmaktadır. Özellikle RBD-spesifik antikorların virüs nötralizasyonunda önemli olduğu düșuinülmektedir ${ }^{[56]}$.

\section{IMMÜN DISREGÜLASYON ve SiTOKIN AȘIRI SALINIMI}

İmmün sistemdeki bazı yapısal ve fonksiyonel bozulmaların da patogenezde etkili olduğu düșünülmektedir. Ciddi solunum yetmezliği gösteren bazı SARS-CoV-2 olgularında hiperinflamatuvar değișikliklere ve makrofaj aktivasyon sendromuna (MAS) rastlanmıștır [57]. MAS, hemofagositik lenfohistiyositoz (HLH)'un bir alt tipi olup yașamı tehdit edici bir durumdur. Ates, hepatosplenomegali, lenfadenopati, hemorajik manifestasyonlar ve sepsis benzeri tablo ile klinikte karșımıza çıar. Klinikte gercek sepsisten ayırmak bir hayli zordur. MAS; sistemik juvenil idiyopatik artrit (SJIA), sistemik lupus eritematozis (SLE), Kawasaki hastalığı $(\mathrm{KH})$, juvenil dermatomiyozit (JDM) gibi otoimmün hastalıklar ile ilișkili veya infeksiyonlarla tetiklenebilen sekonder HLH tipidir. Tanıdaki gecikmeden ve özgül tedavisinin bulunmamasından dolayı mortalite riski yüksektir. Sitopeni, hiperferritinemi ve koagülopati MAS seyrinde görülebilen önemli laboratuvar bulgularıdır. Sitotoksik $\mathrm{T}$ hücreleri ve makrofajlar patogenezde bașrol oynamakla birlikte uzamıs immün aktivasyon, hiperinflamasyon ve 
dolayısıyla hipersitokinemi ve sitokin fırtınası da kısır döngüye katkı sağlamaktadır. IL-6 salınımı bașta olmak üzere IFN- $\gamma$, TNF- $\alpha$, IL-2, IL-1, IL-6, IL-18, makrofaj koloni uyarıcı faktör (M-CSF) gibi cesitli sitokinler hastalık gelișiminde rol almaktadir ${ }^{[58]}$. COVID-19 ile MAS'ın klinik bulguları arasındaki benzerliklerinden ötürü ayırıcı tanıda MAS ihtimali de akılda tutulmalı ve mümkün olduğunca erken müdahale düșuinülmelidir.

Ağır COVID-19 tanısı ile yoğun bakıma yatan hastalarda eritrosit sedimentasyon hızı (ESH), CRP, IL-6, TNF- $\alpha$, IL-1 $\beta$, IL-8, IL2R seviyelerinde artıs görülmektedir. İnflamatuvar göstergelerdeki bu artış; akut solunum sıkıntısı sendromu (ARDS), dissemine intravasküler koagülasyon (DIK) ve hiperkoagülasyonla ilișkilidir ${ }^{[44]}$. Bașka bir calıșmada ise yoğun bakım ünitesinde yatan hastalar yatmayanlarla kıyaslandığında IL-2, IL-7, IL-10, G-CSF, IP10, MCP1, MIP1A, TNF- $\alpha$ düzeylerinde ciddi farkll1ık saptanmıstır [59]. Ciddi COVID-19 hastalığ1, artmıs inflamatuvar sitokin yanıtıyla birliktedir.

İmmün disregülasyonun birçok ayrı kolu vardir. Bunlardan biri monositler tarafından așırı proinflamatuvar sitokin üretimidir. Bir diğeri ise CD4+ lenfosit deplesyonuna bağlı ortaya çıan adaptif immün sistem bozukluklarıdır. Monositlerin hiperaktive olduğu durumda așırı derecede IL-6 salınımı gerçekleșmekte ve bu IL-6 așırı salınımı; özellikle CD14+ monositler olmak üzere antijen sunucu hücrelerde HLA-DR ekspresyonunu ve $\mathrm{CD} 4+$ hücrelerinden IFN- $\gamma$ salınımını azaltmaktadır. Tosilizumab kullanımıyla, HLA-DR ekspresyonu normale dönmektedir. Ayrica tosilizumab tedavisi uygulanmıs bir hasta grubunda lenfosit düzeylerindeki düzelme de IL-6'nın lenfosit sayılarını azaltıcı etkisini ortaya koymaktadır [57]. IL-6, sitokin fırtınasının en önemli tetikleyicilerinden biri olsa da diğer sitokinler de patogeneze direkt katkı sağlamaktadır. IL-1 antagonisti olan anakinra ve kanakinumab da sitokin fırtınasında etkisi araștırılan ilaçlardır ${ }^{[60]}$.

Sitokin salınım sendromu ile MAS; ARDS, solunum yetmezliği ve dolayısıyla kötü prognozla ilișkilidir. Sitokin fırtınası oluşumundaki en kritik molekülün ise IL-6 olduğu görülmektedir. TLR ve IFN- $\gamma$ reseptörü aracılığı ile aktive olan makrofajlar ve monositler, IL-6 sekresyonu yapmaktadır.
IL-6, cis ve trans sinyalizasyonu olarak isimlendirilen iki temel yolak üzerinden özellikle lenfosit ve endotelyal hücreler üzerinde etki göstermektedir. Cis sinyalinde; IL-6, lenfosit yüzeyinde eksprese edilen gp130 kompleksindeki IL-6 reseptörüne bağlanır. JAK/STAT yolağını aktive eder. İkincil mesaj $B$ ve $T$ hücreleri üzerinde bazı etkilere neden olur: T helper 17 (Th17), T folliküler helper (Tfh), CD8+ sitotoksik $\mathrm{T}$ hücre ve aktive $\mathrm{B}$ hücre diferansiyasyonunu artırır; $\mathrm{T}$ regülatör hücre gelișimini baskılar. Regülatör hücrenin azalması, immün yanitın kontrolünü de zorlaștırır. Trans sinyalinde ise; IL-6, cözünür formdaki IL-6 reseptörüne bağlanır ve endotel hücresi gibi membranında IL-6R (mIL-6R) eksprese etmeyen hücrelerde, yine gp130 kompleksi üzerinden JAK/STAT yolağını bașlatır. Bu yolak kan damarlarındaki endotel hücrelerini etkiler: VEGF (vascular endothelial growth factor), MCP-1 (monocyte chemoattractant protein-1), IL-8 ve IL-6 salınımını artırır; E-cadherin sentezini azaltır. Sonucta vasküler permeabilite artar, damardan kaçak bașlar. Bu etkiler hipotansiyon ve ARDS gelisimine katkıda bulunur ve tabloyu daha da ağırlaștırır. Ayrıca IL-6'nın karaciğerin sentez fonksiyonu üzerine de direkt etkileri bulunmaktadır. IL-6; karaciğerden CRP, serum amiloid A, hepsidin, fibrinojen, TPO, C3 ve ferritin salınımını artırır [61]

Kompleman sistemi doğal immün yanıtın bir bileșeni olup konak savunmasında önemli bir rol üstlenmektedir. Fakat kontrol edilemeyen așırı kompleman sistemi yanıtı akut akciğer hasarı olusumuna sebep olur. C5a, fagositik hücreleri aktive eder. Aktive hücrelerden sitokin salınımı uyarır ve sitokin firtınasına neden olabilir. C5a; mast hücrelerini, nötrofilleri, monosit ve makrofajları indükler ve IL-12, TNF- $\alpha$ ve MIP-1 $\alpha$ (macrophage inflammatory protein-1 $\alpha$ ) gibi proinflamatuvar sitokinlerin salınımına neden olur. Ayrıca $B$ ve $T$ hücrelerini de stimüle ederek TNF- $\alpha$, IL-1 $\beta$, IL-6 ve IL-8 gibi sitokinlerin salınımına da neden olabilmektedir. Doğrudan ve TNF- $\alpha$ üzerinden dolaylı olarak, IL-6 salınımına yol açabilmektedir. C5a, TLR'yi indükleyerek ERK 1/2 (extracellular-signal-regulated kinase 1/2) aracılığıyla IL-8 salınımını arttırır. C5a etkisini antijen sunucu hücrelerdeki C5aR sayesinde göstermektedir. C5aR'nin, CD4+ 
T hücre proliferasyonu ve diferansiyasyonu üzerinde etkileri vardir. Ayrıca C5aR, CD8+ T hücre aktivasyonunda da rol alır. Tüm bunlar birlikte düșünüldüğünde C5a; gerek doğal gerekse edinsel immün sistem üzerinden proinflamatuvar sitokin salınımını artırarak sitokin fırtınası ve ARDS olusumuna katkı sağlayabilir. Așırı C5a salınımının ciddi solunum yetmezliği gelișiminde rol alabileceği düșünülmektedir ${ }^{[62,63]}$

\section{CIDDi SOLUNUM YETMEZLiĞí GELIȘiMi}

ARDS'ye ilerleyen patogenez yolağı birkaç mekanizmayla ișlemekte ve ölümle sonuçlanabilen ciddi solunum yetmezliğine yol açmaktadır. Alt solunum yollarına ulașan SARS-CoV-2 buradan kana geçerek hafif düzeyde viremiye yol açarak asemptomatik seyredebileceği gibi domino tașları gibi birbirine bağlı bir dizi olayı tetikleyerek ARDS gelișimine de sebebiyet verebilir. Bu yollar așağıda kısaca özetlenmeye calıșılmıștır ${ }^{[5]}$.

Virüsün hücre içine giriși sırasında baskılanan ve ortama saçllıma uğrayan ACE2, RAS üzerinden pulmoner damar geçirgenliğini etkileyerek akciğer ödemine yol açabilir.

$T$ hücre așırı aktivasyonu aracılığıyla immün disfonksiyonda rol alabilir.

Anti-S-IgG, ADE fenomeni aracılığıla birçok hücre tipini uyararak sistemik inflamatuvar yanıt olusturabilir; viral sepsise ve coklu organ hasarına neden olabilir.

COVID-19 hastalığının yeni anlașılmaya bașlanan bir bileșeni de damar sistemi üzerine yaptığı etkilerdir. Eldeki veriler, hastalığın trombozdan bağımsız olarak mikroanjiyopati yaptığını ve mikroanjiyopatinin sadece akciğer ile sınırlı olmadığını göstermektedir (İdilman İ, İnkaya AC et al. Yayımlanmamıs veri. 2020).

Özetlenmeye calıșlan immün disfonksiyon, sistemik inflamatuvar yanit ve RAS disfonksiyonu hepsi birlikte sitokin fırtınası oluşmasına katkıda bulunabilir. COVID-19; sitokin fırtınası, pulmoner ödem ve organ hasarları kontrol altına alınamadığı takdirde de ARDS ve solunum yetmezliğine bağlı ölümle sonuçlanabilir ${ }^{[5]}$.

\section{HIPERKOAGÜLASYON}

SARS-CoV-2'ye bağlı ciddi pnömonisi olan birçok olguda koagülasyonda artış gözlenmiștir.
Koagülopatili hastalarda mortalite yüksekliği, koagülasyonun COVID-19 patogenezinde önemli bir rolü olabileceğine ișaret etmektedir ${ }^{[64]}$. Özellikle D-dimer düzeyi $3 \mu \mathrm{g} / \mathrm{mL}$ 'nin üzerinde olan hastaların heparin tedavisinden ciddi fayda görmesi ve antikoagülan tedavi sayesinde mortalitenin azalması bu gözlemleri doğrulamaktadır. Hiperkoagülasyon durumu; inme gibi serebrovasküler olaylar, pulmoner tromboemboli gibi kardiyovasküler olaylar, gebelik kaybı, arteriyel ve venöz tromboz ve osteonekroz gibi ciddi sonuçlara yol açabilir ${ }^{[65]}$. Hiperkoagülasyona yol açabilecek olası mekanizmalar sunlardir:

i. Solunum yetmezliğinin neden olduğu hipoksi, hipoksiyle indüklenen transkripsiyon faktörüne (HIF; hypoxia-inducible transcription factor) bağlı sinyal yolağını uyarabilir veya direkt kan viskozitesini artırabilir ${ }^{[64,66]}$.

ii. Pulmoner hiperinflamasyon TPO seviyesi artıșına yol açabilir. Bu da trombositoza ve dolayısıyla tromboz eğilimine yol açabilir ${ }^{[64]}$

iii. Sitokin fırtınası koagülasyon kaskadının aktivasyonunda artıșa neden olabilir ${ }^{[67]}$.

iv. Daha önceki birçok çalıșmada; hepatit C virüsü, HIV, sitomegalovirüs, varisella-zoster virüs, Epstein-Barr virüs, adenovirüs, parvovirüs $\mathrm{B}$ gibi viral infeksiyonlara sekonder, antifosfolipid antikor üretimi olabileceği gözlenmiștir. Virüs tarafından uyarılan antifosfolipid sendromu COVID-19 hastalarında da dikkat çekmiștir. Bu doğrultuda yapılan incelemelerde özellikle altta yatan hipertansiyon ve diyabet gibi komorbid hastalıkları bulunan multipl serebral infarkt gecirmis bir grup ileri yașlı hastada, antikardiyolipin IgA, anti- $\beta 2$-glikoprotein I IgA ve IgG antikorlarına rastlanmıș olup bu hastalar antifosfolipid sendromu ile uyumlu bulunmustur. SARS-CoV-2'nin bu tip antikorların olușumunda anlamlı bir sekilde etkili olup olmadı̆̆ı ileri araștırma gerektiren önemli bir konudur ${ }^{[68]}$.

v. Virüsün bağlanması ile hücre içerisine geçen ACE2 enziminin destrükte olması sonucu gözlenen sistemik ve lokal anjiyotensin 2 artıșının da tromboz gelișimi için kolaylaștırıcı etkisi olabileceği düșünülmektedir ${ }^{[20] .}$ 
vi. Endotel hasarına bağlı olarak koagülasyon kaskadının aktive olması da aynı sekilde hiperkoagüle durumun ortaya çııșının en gücliu sebeplerinden biri gibi gözükmektedir ${ }^{[19]}$.

\section{SONUC}

SARS-CoV-2 hala tüm dünyayı tehdit eden ve cok hızlı yayılabilen bir virüstür. Yol açtığı COVID-19 bașta solunum yolları olmak üzere birçok dokuda ciddi patolojilere yol açabilmekte ve coklu organ hasarına kadar ilerleyebilen yaygin sistemik komplikasyonlara sebep olabilmektedir. SARS-CoV-2 asemptomatik olabileceği gibi ARDS, solunum yetmezliği, MAS, DIK, yaygın tromboemboli ve hatta ölüm gibi ciddi durumlarla da sonuclanabilmektedir. Semptomatik tedavi ve yoğun bakım desteği ile hastaların büyük coğunluğunun iyileșmesi sağlanabilse de spesifik tedavisi henüz bulunamamıștır. Virüs yayılımının etkin ve kalıcı sekilde kontrolünün sağlanması için așıya ihtiyaç duyulmaktadır. Tüm dünyadaki çeșitli merkezlerde așı ve spesifik tedavi bulma çabaları tüm hızıyla devam etmektedir. Așı ve tedavinin bulunabilmesi ise ancak hastalığın patogenez yolaklarının ve virüs immünolojisinin açıça tanımlanabilmesi ile mümkündür. $\mathrm{Bu}$ derlemede; daha önceki SARS-CoV salgınından elde edilen deneyimler ile SARS-CoV-2 üzerine yapilan calıșmalar sonucunda ortaya cıkan veriler incelenerek virüsün immün patogenezi aydınlatılmaya calıșılmıștır. Hala üzerinde ileri araștırma gereken noktalar olmakla birlikte hastalığın insanda ortaya çıkısı ve ağırlașmasının arkasında yatan immün patogenezin aydınlatılmasında büyuik yol katedilmiștir. Hastalığın uzun dönem sonuçlarının ne olacağı ise hala büyük bir merak konusudur.

\section{TEŞEKKÜR}

Yazarlar, makale taslağını yapıcı elestirilerle geliștiren Stj. Dr. Ezgi Aysu Şahin'e teșekkür eder.

\section{ÇIKAR ÇATIȘMASI}

Yazarlar bu makale ile ilgili herhangi bir çkar catıșması bildirmemișlerdir.

\section{KAYNAKLAR}

1. Lu H, Stratton CW, Tang YW. Outbreak of pneumonia of unknown etiology in Wuhan, China: The mystery and the miracle. J Med Virol 2020;92(4):401-2.
2. Gorbalenya AE, Baker SC, Baric RS, de Groot RJ, Drosten $C$, Gulyaeva $A A$, et al. Severe acute respiratory syndrome-related coronavirus: the species and its viruses - a statement of the Coronavirus Study Group. bioRxiv 2020:2020.02.07.937862.

3. Zhao S, Lin Q, Ran J, Musa SS, Yang G, Wang W, et al. Preliminary estimation of the basic reproduction number of novel coronavirus (2019-nCoV) in China, from 2019 to 2020: $A$ data-driven analysis in the early phase of the outbreak. Int J Infect Dis 2020 Mar;92:214-7.

4. World Health Organization (WHO). [cited 202016 May]; Available from: http://www.who.int

5. Jin Y, Yang H, Ji W, Wu W, Chen S, Zhang W, et al. Virology, epidemiology, pathogenesis, and control of COVID-19. Viruses 2020 Mar 27;12(4).

6. Lin YS, Lin CF, Fang YT, Kuo YM, Liao PC, Yeh TM, et al. Antibody to severe acute respiratory syndrome (SARS)-associated coronavirus spike protein domain 2 cross-reacts with lung epithelial cells and causes cytotoxicity. Clin Exp Immunol 2005; 141(3):500-8.

7. Su S, Wong G, Shi W, Liu J, Lai ACK, Zhou J, et al. Epidemiology, genetic recombination, and pathogenesis of coronaviruses. Trends Microbiol 2016;24(6):490-502.

8. Lu R, Zhao X, Li J, Niu P, Yang B, Wu H, et al. Genomic characterisation and epidemiology of 2019 novel coronavirus: implications for virus origins and receptor binding. Lancet 2020 Feb 22;395(10224):565-74.

9. Peiris JS, Guan Y, Yuen KY. Severe acute respiratory syndrome. Nat Med 2004;10(12 Suppl):S88-97.

10. Zaki AM, van Boheemen S, Bestebroer TM, Osterhaus $A D M E$, Fouchier RAM. Isolation of a novel coronavirus from a man with pneumonia in Saudi Arabia. N Engl J Med 2012;367(19):1814-20.

11. Zhang Y, Geng X, Tan Y, Li Q, Xu C, Xu J, et al. New understanding of the damage of SARS-CoV-2 infection outside the respiratory system. Biomed Pharmacother $2020 \mathrm{Apr}$ 28;127:110195.

12. Chen $Y$, Liu Q, Guo D. Emerging coronaviruses: genome structure, replication, and pathogenesis. I Med Virol 2020 Apr;92(4):418-23.

13. Li X, Geng M, Peng Y, Meng L, Lu S. Molecular immune pathogenesis and diagnosis of COVID-19. J Pharm Anal 2020 Mar 5.

14. Beniac DR, Andonov A, Grudeski E, Booth TF. Architecture of the SARS coronavirus prefusion spike. Nat Struct Mol Biol 2006;13(8):751-2.

15. Nal B, Chan C, Kien F, Siu L, Tse J, Chu K, et al. Differential maturation and subcellular localization of severe acute respiratory syndrome coronavirus surface proteins $S, M$ and $E$. J Gen Virol 2005;86(5):1423-34.

16. Fehr AR, Perlman S. Coronaviruses: an overview of their replication and pathogenesis. Methods Mol Biol 2015;1282:1 23. 
17. Belouzard S, Chu VC, Whittaker GR. Activation of the SARS coronavirus spike protein via sequential proteolytic cleavage at two distinct sites. Proc Natl Acad Sci U S A 2009 Apr 7;106(14):5871-6.

18. Li Y, Zhang Z, Yang L, Lian X, Xie Y, Li S, et al. The MERSCoV receptor DPP4 as a candidate binding target of the SARS-CoV-2 spike. iScience 2020 2020/05/13/:101160.

19. Varga Z, Flammer AJ, Steiger $P$, Haberecker $M$, Andermatt $R$, Zinkernagel AS, et al. Endothelial cell infection and endotheliitis in COVID-19. The Lancet 2020;395(10234):14178.

20. Magro C, Mulvey JJ, Berlin D, Nuovo G, Salvatore S, Harp J, et al. Complement associated microvascular injury and thrombosis in the pathogenesis of severe COVID-19 infection: a report of five cases. Transl Res 2020 Apr 15.

21. Yip MS, Leung HL, Li PH, Cheung CY, Dutry I, Li D, et al. Antibody-dependent enhancement of SARS coronavirus infection and its role in the pathogenesis of SARS. Hong Kong Med J 2016;22(3 Suppl 4):S25-31.

22. Wang SF, Tseng SP, Yen CH, Yang JY, Tsao CH, Shen CW, et al. Antibody-dependent SARS coronavirus infection is mediated by antibodies against spike proteins. Biochem Biophys Res Commun 2014;451(2):208-14.

23. Wang $X, X u W, H u G, X i a S$, Sun Z, Liu Z, et al. SARS-CoV-2 infects $T$ lymphocytes through its spike protein-mediated membrane fusion. Cell Mol Immunol $2020 \mathrm{Apr} 7$.

24. Chu H, Zhou J, Wong BH, Li C, Chan JF, Cheng ZS, et al. Middle East respiratory syndrome coronavirus efficiently infects human primary $T$ lymphocytes and activates the extrinsic and intrinsic apoptosis pathways. I Infect Dis 2016;213(6):904-14.

25. Wang K, Chen W, Zhou YS, Lian JQ, Zhang Z, Du P, et al. SARS-CoV-2 invades host cells via a novel route: CD147-spike protein. bioRxiv 2020:2020.03.14.988345

26. Li G, Fan $Y$, Lai $Y$, Han $T$, Li Z, Zhou P, et al. Coronavirus infections and immune responses. J Med Virol 2020;92(4):42432 .

27. Snijder EJ, van der Meer Y, Zevenhoven-Dobbe J, Onderwater JJ, van der Meulen J, Koerten HK, et al. Ultrastructure and origin of membrane vesicles associated with the severe acute respiratory syndrome coronavirus replication complex. J Virol 2006;80(12):5927-40.

28. Channappanavar R, Fehr AR, Vijay R, Mack M, Zhao J, Meyerholz DK, et al. Dysregulated type I interferon and inflammatory monocyte-macrophage responses cause lethal pneumonia in SARS-CoV-infected mice. Cell Host Microbe 2016;19(2):181-93.

29. Channappanavar R, Fehr AR, Zheng J, Wohlford-Lenane C, Abrahante JE, Mack $M$, et al. IFN-I response timing relative to virus replication determines MERS coronavirus infection outcomes. J Clin Invest 2019;130(9):3625-39.

30. Keicho N, Itoyama S, Kashiwase K, Phi NC, Long HT, Ha LD, et al. Association of human leukocyte antigen class II alleles with severe acute respiratory syndrome in the Vietnamese population. Hum Immunol 2009;70(7):527-31.
31. Chen YM, Liang SY, Shih YP, Chen $C Y$, Lee YM, Chang L, et al. Epidemiological and genetic correlates of severe acute respiratory syndrome coronavirus infection in the hospital with the highest nosocomial infection rate in Taiwan in 2003. J Clin Microbiol 2006;44(2):359-65.

32. Wang SF, Chen $K H$, Chen $M$, Li WY, Chen YJ, Tsao CH, et al. Human-leukocyte antigen class I CW 1502 and class II DR 0301 genotypes are associated with resistance to severe acute respiratory syndrome (SARS) infection. Viral Immunology $20112011 / 10 / 01 ; 24(5): 421-6$.

33. Tu X, Chong WP, Zhai Y, Zhang H, Zhang F, Wang S, et al. Functional polymorphisms of the CCL2 and MBL genes Cumulatively increase susceptibility to severe acute respiratory syndrome coronavirus infection. J Infect 2015;71(1):101-9.

34. Hajeer AH, Balkhy $H$, Johani S, Yousef MZ, Arabi Y. Association of human leukocyte antigen class II alleles with severe Middle East respiratory syndrome-coronavirus infection. Ann Thorac Med 2016;11(3):211-3.

35. Kopecky-Bromberg SA, Martinez-Sobrido L, Frieman $M$, Baric RA, Palese $P$. Severe acute respiratory syndrome coronavirus open reading frame (ORF) 3b, ORF 6, and nucleocapsid proteins function as interferon antagonists. J Virol 2007;81(2):548-57.

36. Lu X, Pan J, Tao J, Guo D. SARS-CoV nucleocapsid protein antagonizes IFN- $\beta$ response by targeting initial step of IFN- $\beta$ induction pathway, and its C-terminal region is critical for the antagonism. Virus Genes 2011;42(1):37-45.

37. Cecere TE, Todd SM, Leroith T. Regulatory T cells in arterivirus and coronavirus infections: do they protect against disease or enhance it? Viruses 2012;4(5):833-46.

38. Zhao J, Li K, Wohlford-Lenane C, Agnihothram SS, Fett C, Zhao J, et al. Rapid generation of a mouse model for Middle East respiratory syndrome. Proc Natl Acad Sci U S A 2014;111(13):4970-5.

39. Ganji A, Farahani I, Khansarinejad B, Ghazavi A, Mosayebi $G$. Increased expression of CD8 marker on T-celIs in COVID-19 patients. Blood Cells Mol Dis $2020 \mathrm{Apr}$ 13;83:102437.

40. Janice Oh HL, Ken-En Gan S, Bertoletti A, Tan YJ. Understanding the $T$ cell immune response in SARS coronavirus infection. Emerg Microbes Infect 2012;1(9):e23.

41. Wang F, Nie J, Wang H, Zhao Q, Xiong Y, Deng L, et al. Characteristics of peripheral lymphocyte subset alteration in COVID-19 pneumonia. J Infect Dis 2020 Mar 30.

42. Qin C, Zhou L, Hu Z, Zhang S, Yang S, Tao Y, et al. Dysregulation of immune response in patients with COVID-19 in Wuhan, China. Clin Infect Dis 2020 Mar 12.

43. Xu Z, Shi L, Wang Y, Zhang J, Huang L, Zhang C, et al. Pathological findings of COVID-19 associated with acute respiratory distress syndrome. Lancet Respir Med 2020 Apr;8(4):420-2.

44. Zhang $W$, Zhao $Y$, Zhang F, Wang Q, Li T, Liu Z, et al. The use of anti-inflammatory drugs in the treatment of people with severe coronavirus disease 2019 (COVID-19): The perspectives of clinical immunologists from China. Clin Immunol 2020 May;214:108393. 
45. Chen J, Lau YF, Lamirande EW, Paddock CD, Bartlett JH, Zaki SR, et al. Cellular immune responses to severe acute respiratory syndrome coronavirus (SARS-CoV) infection in senescent BALB/c mice: $C D 4+T$ cells are important in control of SARS-CoV infection. J Virol 2010;84(3):1289-301.

46. Ababneh $M$, Alrwashdeh $M$, Khalifeh M. Recombinant adenoviral vaccine encoding the spike 1 subunit of the Middle East respiratory syndrome coronavirus elicits strong humoral and cellular immune responses in mice. Vet World 2019;12(10):1554-62.

47. Ali MT, Morshed MM, Gazi MA, Musa MA, Kibria MG, Ud$\operatorname{din} M J$, et al. Computer aided prediction and identification of potential epitopes in the receptor binding domain (RBD) of spike (S) glycoprotein of MERS-CoV. Bioinformation 2014;10(8):533-8

48. Ying $T, D u L$, Ju TW, Prabakaran P, Lau CC, Lu L, et al. Exceptionally potent neutralization of Middle East respiratory syndrome coronavirus by human monoclonal antibodies. J Virol 2014;88(14):7796-805.

49. Houser KV, Gretebeck L, Ying T, Wang Y, Vogel L, Lamirande $E W$, et al. Prophylaxis with a Middle East respiratory syndrome coronavirus (MERS-CoV)-specific human monoclonal antibody protects rabbits from MERS-CoV infection. I Infect Dis 2016;213(10):1557-61.

50. van Doremalen $N$, Falzarano D, Ying $T$, de Wit E, Bushmaker $T$, Feldmann $F$, et al. Efficacy of antibody-based therapies against Middle East respiratory syndrome coronavirus (MERS-CoV) in common marmosets. Antiviral Res 2017; 143:30-7.

51. Zhao J, Yuan Q, Wang H, Liu W, Liao X, Su Y, et al. Antibody responses to SARS-CoV-2 in patients of novel coronavirus disease 2019. Clin Infect Dis 2020 Mar 28.

52. Chen $W, X u Z, M u$ J, Yang L, Gan H, Mu F, et al. Antibody response and viraemia during the course of severe acute respiratory syndrome (SARS)-associated coronavirus infection. J Med Microbiol 2004;53(Pt 5):435-8.

53. Iwasaki A, Yang Y. The potential danger of suboptimal antibody responses in COVID-19. Nat Rev Immunol $2020 \mathrm{Apr}$ 21.

54. Yasui F, Kai C, Kitabatake M, Inoue S, Yoneda M, Yokochi $S$, et al. Prior immunization with severe acute respiratory syndrome (SARS)-associated coronavirus (SARS-CoV) nucleocapsid protein causes severe pneumonia in mice infected with SARS-CoV. J Immunol 2008;181(9):6337-48.

55. Tan W, Lu Y, Zhang J, Wang J, Dan Y, Tan Z, et al. Viral kinetics and antibody responses in patients with COVID-19. medRxiv 2020:2020.03.24.20042382.

56. Suthar MS, Zimmerman M, Kauffman R, Mantus G, Linderman $S$, Vanderheiden $A$, et al. Rapid generation of neutralizing antibody responses in COVID-19 patients. medRxiv 2020:2020.05.03.20084442.
57. Giamarellos-Bourboulis EJ, Netea MG, Rovina N, Akinosoglou K, Antoniadou A, Antonakos N, et al. Complex immune dysregulation in COVID-19 patients with severe respiratory failure. Cell Host Microbe 2020 Apr 17.

58. Lerkvaleekul B, Vilaiyuk S. Macrophage activation syndrome: early diagnosis is key. Open Access Rheumatol 2018;10:117-28.

59. Huang C, Wang Y, Li X, Ren L, Zhao J, Hu Y, et al. Clinical features of patients infected with 2019 novel coronavirus in Wuhan, China. Lancet 2020 Feb 15;395(10223):497506.

60. Henderson LA, Canna SW, Schulert GS, Volpi S, Lee PY, Kernan $K F$, et al. On the alert for cytokine storm: immunopathology in COVID-19. Arthritis Rheumatol $n / a(n / a)$.

61. Moore JB, June $\mathrm{CH}$. Cytokine release syndrome in severe COVID-19. Science 2020;368(6490):473-4.

62. Wang $R$, Xiao H, Guo R, Li Y, Shen B. The role of C5a in acute lung injury induced by highly pathogenic viral infections. Emerg Microbes Infect 2015:2015/01/01;4(1):1-7.

63. Maglakelidze N, Manto KM, Craig TJ. Does complement or the contact system have a role in protection or pathogenesis of COVID-19? Pulm Ther 2020 May 13:1-8.

64. Yin S, Huang M, Li D, Tang N. Difference of coagulation features between severe pneumonia induced by SARS-CoV2 and non-SARS-CoV2. I Thromb Thrombolysis 2020 Apr 3.

65. Sun W, Wang BL, Liu BL, Zhao FC, Shi ZC, Guo WS, et al. Osteonecrosis in patients after severe acute respiratory syndrome (SARS): possible role of anticardiolipin antibodies. J Clin Rheumatol 2010 Mar; 16(2):61-3.

66. Gupta N, Zhao YY, Evans CE. The stimulation of thrombosis by hypoxia. Thromb Res 2019;181:77-83.

67. Dolhnikoff $M$, Duarte-Neto AN, de Almeida Monteiro RA, Ferraz da Silva LF, Pierre de Oliveira E, Nascimento Saldiva $\mathrm{PH}$, et al. Pathological evidence of pulmonary thrombotic phenomena in severe COVID-19. I Thromb Haemost 2020 Apr 15.

68. Zhang $Y$, Xiao $M$, Zhang S, Xia $P$, Cao $W$, Jiang $W$, et al. Coagulopathy and antiphospholipid antibodies in patients with COVID-19. N Engl J Med 2020:e38.

\section{Yazıșma Adresi/Address for Correspondence}

Doç. Dr. Ahmet Cağkan İNKAYA

Hacettepe Üniversitesi Tıp Fakültesi, İnfeksiyon Hastalıkları ve

Klinik Mikrobiyoloji Anabilim Dal,,

Ankara-Türkiye

E-posta: inkayaac@yahoo.com 